\title{
BAY 41-2272 Attenuates CTGF Expression via sGC/cGMP-Independent Pathway in TGFß1-Activated Hepatic Stellate Cells
}

\author{
Po-Jen Chen ${ }^{1,+}{ }^{+}$, Liang-Mou Kuo ${ }^{2,+}$, Yi-Hsiu Wu ${ }^{3}$, Yu-Chia Chang ${ }^{4}\left(\mathbb{D}\right.$, Kuei-Hung Lai ${ }^{4,5}{ }^{(}$and \\ Tsong-Long Hwang $3,4,6,7,8, *$ (D) \\ 1 Department of Cosmetic Science, Providence University, Taichung 433719, Taiwan; litlep@hotmail.com \\ 2 Department of General Surgery, Chang Gung Memorial Hospital at Chiayi, Chiayi 613016, Taiwan; \\ kuo33410@yahoo.com.tw \\ 3 Graduate Institute of Natural Products, College of Medicine, Chang Gung University, \\ Taoyuan 333323, Taiwan; modemtw@gmail.com \\ 4 Research Center for Chinese Herbal Medicine, Graduate Institute of Health Industry Technology, \\ College of Human Ecology, Chang Gung University of Science and Technology, Taoyuan 333323, Taiwan; \\ ycchang03@mail.cgust.edu.tw (Y.-C.C.); mos19880822@gmail.com (K.-H.L.) \\ 5 Graduate Institute of Pharmacognosy, College of Pharmacy, Taipei Medical University, Taipei 110301, Taiwan \\ 6 Research Center for Food and Cosmetic Safety, College of Human Ecology, Chang Gung University of \\ Science and Technology, Taoyuan 333323, Taiwan \\ 7 Department of Anaesthesiology, Chang Gung Memorial Hospital, Taoyuan 333423, Taiwan \\ 8 Department of Chemical Engineering, Ming Chi University of Technology, New Taipei City 243303, Taiwan \\ * Correspondence: htl@mail.cgu.edu.tw; Tel.: +886-3-211-8800 (ext. 5523) \\ + These authors contributed equally to this work.
}

Received: 3 August 2020; Accepted: 3 September 2020; Published: 4 September 2020

\begin{abstract}
Activation of hepatic stellate cells (HSCs) is a critical pathogenic feature of liver fibrosis and cirrhosis. BAY 41-2272 is a canonical non-nitric oxide (NO)-based soluble guanylyl cyclase (sGC) stimulator that triggers cyclic guanosine monophosphate (cGMP) signaling for attenuation of fibrotic disorders; however, the impact of BAY 41-2272 on HSC activation remains ill-defined. Transforming growth factor (TGF) $\beta$ and its downstream connective tissue growth factor (CTGF or cellular communication network factor 2, CCN2) are critical fibrogenic cytokines for accelerating HSC activation. Here, we identified that BAY 41-2272 significantly inhibited the TGF $\beta 1$-induced mRNA and protein expression of CTGF in mouse primary HSCs. Indeed, BAY 41-2272 increased the sGC activity and cGMP levels that were potentiated by two NO donors and inhibited by a specific sGC inhibitor, ODQ. Surprisingly, the inhibitory effects of BAY 41-2272 on CTGF expression were independent of the sGC/cGMP pathway in TGF 31 -activated primary HSCs. BAY 41-2272 selectively restricted the TGF $\beta 1$-induced phosphorylation of Akt but not canonical Smad2/3 in primary HSCs. Together, we illustrate a unique framework of BAY 41-2272 for inhibiting TGF $\beta 1$-induced CTGF upregulation and HSC activation via a noncanonical Akt-dependent but sGC/cGMP-independent pathway.
\end{abstract}

Keywords: Akt; BAY 41-2272; CTGF; hepatic stellate cell; sGC

\section{Introduction}

The overwhelming activation and proliferation of hepatic stellate cells (HSCs) is an important factor in hepatic fibrosis, an advanced pathogenic condition in liver cirrhosis, portal hypertension, and hepatocellular carcinoma. During acute or chronic injuries, star-like shaped HSCs shift from quiescent non-proliferative status to active state with contractile, proliferative, and fibrogenic properties, 
leading to pro-inflammatory growth factor generation and extracellular matrix (ECM) protein production to initiate matrix deposition in the liver [1-3]. Targeting activated HSCs has been proposed as a potential strategy to remedy liver diseases, returning activated HSCs to a quiescent status or repressing proliferation of activated HSCs. Therefore, identification of anti-fibrotic agents and their underlying molecular mechanisms of action is desirable for removing factors causing HSC activation [4-7].

The nitric oxide (NO)/soluble guanylate cyclase (sGC)/cyclic guanosine monophosphate (cGMP) pathway tightly controls important physiological functions in several human body organs; therefore, it has been considered as a worthwhile therapeutic target for many diseases including cardiopulmonary, neuronal, and fibrotic disorders [8-11]. sGC is a heterodimeric enzyme catalyzing the conversion of GTP to cGMP. The activation of native reduced sGC is canonically triggered by NO that in turn binds to the heme moiety of sGC to produce cGMP. There are various small molecules, sGC stimulators and sGC activators, that induce the activity of heme-dependent reduced sGC and heme-independent oxidized sGC, respectively [12,13]. Emerging evidence suggests that both sGC stimulators and activators affect tissue fibrosis inhibition via elevating intracellular levels of cGMP [11,14,15]; hence, pharmacological induction of sGC may be a promising approach to impede HSC activation.

Transforming growth factor (TGF) $\beta$ is a pivotal fibrogenic cytokine to stimulate HSC activation. The TGF $\beta$ levels are typically low in quiescent HSCs but are upregulated and released from deposits in the ECM after liver injury. TGF $\beta$ s activate HSCs for adaptation of fibroblast shape, contractility, proliferation, and migratory phenotype [16-18]. Targeting the local TGF $\beta$ activity or inhibiting TGF $\beta$ signaling is ideal for affecting HSC activation, which is the focus of this research strategy. The TGF $\beta$-induced activation of HSCs during liver fibrosis takes place via canonical Smad-dependent or noncanonical Smad-independent signaling such as the Akt pathway [18,19]. It has been documented that TGF $\beta$ induced the connective-tissue growth factor (CTGF or cellular communication network factor 2, CCN2) expression via Smad and Stat3 signaling pathways in HSCs [20]. The pro-fibrotic CTGF is also upregulated and promotes the pathogenic process of liver fibrosis including cell proliferation, contractility, migration, and ECM production in activated HSCs [21-23]. The TGF $\beta-C T G F$ axis serves as a promising pathogenic pathway to affect HSC activation; however, its regulatory signaling is still elusive.

BAY 41-2272 is a regular non-nitric oxide (NO)-based sGC stimulator and is used to ameliorate the fibrosis in the lung, systemic sclerosis, peritoneal stripping, pulmonary hypertension, cardiomyocyte hypertrophy, and chronic renal disease [24-29]. To date, no studies have addressed the impact of BAY 41-2272 on HSC activation in detail. We investigated the possible capacity of BAY 41-2272 to affect sGC/cGMP in TGF $\beta 1$-activated mouse-primary HSCs. In the present study, BAY 41-2272 significantly attenuated the TGF $\beta 1$-induced CTGF expression and cell proliferation in primary HSCs. Unexpectedly, the inhibitory effects of BAY 41-2272 on CTGF upregulation were independent on the sGC/cGMP pathway. BAY 41-2272 alternatively inhibited the noncanonical Akt instead of canonical Smad2/3 pathway in TGF $\beta 1$-primed HSCs. Our findings provide a mechanistic basis for BAY 41-2272 activity as a potential agent for Akt-dependent inhibition of TGF $\beta 1$-instigated CTGF induction and HSC activation that is distinct from the canonical sGC/cGMP and Smad signaling.

\section{Experimental Section}

\subsection{Reagents}

BAY 41-2272 was purchased from Calbiochem (La Jolla, CA, USA). BAY 58-2667 was obtained from BioVision (Mountain, PA, USA). Recombinant human TGF $\beta 1$ was from R\&D Systems (Minneapolis, MN, USA). TRIzol reagents were from Thermo Fisher Scientific (Waltham, MA, USA). iScript cDNA synthesis kit and power SYBR green PCR master mix were purchased from Bio-Rad (Hercules, CA, USA). WST-1 Assay Kit was obtained from Roche Applied Sciences (Mannheim, Germany). Antibodies against phospho-Akt (S473), phospho-Akt (T308), Akt, phospho-Smad2, phospho-Smad3, and Smad2/3 were 
purchased from Cell Signaling Technology (Beverly, MA, USA). Antibodies against GAPDH and CTGF were obtained from Santa Cruz Biotechnology (Santa Cruz, CA, USA). Other chemicals were purchased from Sigma (St. Louis, MO, USA).

\subsection{Isolation of Mouse Primary HSCs}

The study was approved by and followed the guidelines of the Institutional Animal Care and Use Committee of Chang Gung University, Taiwan (IACUC approval No.: CGU15-085 and date: 11 November 2015). We purchased 8- to 10-week-old C57BL/6 male mice from BioLASCO (Taiwan). Five mice were kept in a cage under a 12-12-h light-dark cycle and were provided with water and food. HSCs were isolated from livers of 8- to 10-week-old C57BL/6 male mice using a modified, previously described procedure [30,31]. Briefly, mice were euthanized by $\mathrm{CO}_{2}$ and perfused with normal saline via the inferior vena cava followed by injection with $0.1 \%(w / v)$ collagenase IV in HBSS. Livers were taken out and agitated in $0.1 \%(w / v)$ collagenase IV at $37^{\circ} \mathrm{C}$ for $10 \mathrm{~min}$. Cells were filtered through a nylon mesh and purified via Percoll gradient centrifugation. The isolated HSCs were cultured in Roswell Park Memorial Institute (RPMI) 1640 media supplemented with $10 \%$ fetal bovine serum and $10 \%$ horse serum at $37^{\circ} \mathrm{C}$ in a humidified incubator with $5 \% \mathrm{CO}_{2}$. The purity of $\mathrm{HSC}$ was above $95 \%$, as confirmed by their astrocytes, intracellular lipid droplets, and vitamin A autofluorescence [32]. HSCs were cultured for 7 days and then spread out as the next generation. The fifth to seventh generation of HSCs were seeded overnight for the following experiments.

\subsection{Cell Viability}

HSCs were cultured and starved in RPMI 1640 media for $24 \mathrm{~h}$. Cells were treated with indicated compounds and then activated with TGF $\beta 1(5 \mathrm{ng} / \mathrm{mL})$ for 0,24 , or $48 \mathrm{~h}$. Cells were subsequently incubated with the WST-1 reagent at $37^{\circ} \mathrm{C}$ for $2 \mathrm{~h}$. The cell viability was monitored spectrophotometrically at $450 \mathrm{~nm}$ (Thermo Fisher Scientific; Waltham, MA, USA).

\subsection{Western Blotting}

Cell pellets were suspended in lysis buffer (50 mM 4-(2-hydroxyethyl)-1-piperazineethanesulfonic acid (HEPES), $100 \mathrm{mM} \mathrm{NaCl}, 1 \mathrm{mM}$ ethylenediaminetetraacetic acid (EDTA), $2 \mathrm{mM} \mathrm{Na}_{3} \mathrm{VO}_{4}, 5 \%$ 2-mercaptoethanol, and $1 \%$ Triton-X-100) and then centrifuged at $14,000 \times g$ for $20 \mathrm{~min}$ at $4{ }^{\circ} \mathrm{C}$. Total protein concentration were determined by using a BCA Protein Assay Kit (Pierce, Rockford, IL, USA). We mixed $30 \mu \mathrm{g}$ cell lysates with sample buffer (62.5 mM Tris- $\mathrm{HCl}$ ( $\mathrm{pH} 6.8), 4 \%$ SDS, 5\% $\beta$-mercaptoethanol, $2.5 \mathrm{mM} \mathrm{Na}_{3} \mathrm{VO}_{4}, 0.0125 \%$ bromophenol blue, $10 \mathrm{mM}$ di-N-pentyl phthalate, and $8.75 \%$ glycerol) at $100{ }^{\circ} \mathrm{C}$ for $5 \mathrm{~min}$, separated by $10 \%$ or $12 \%$ sodium dodecyl sulfate polyacrylamide gel electrophoresis (SDS-PAGE), electrophoresed onto a nitrocellulose membrane, and assayed by immunoblotting with specific primary antibodies against phospho-Akt S473 (catalog no. 4060, Cell Signaling), phospho-Akt T308 (catalog no. 2965, Cell Signaling), Akt (catalog no. 4691, Cell Signaling), phospho-Smad2 (catalog no. 3108, Cell Signaling), phospho-Smad3 (catalog no. 9520, Cell Signaling), Smad2/3 (catalog no. 5678, Cell Signaling), GAPDH (catalog no. sc-32233, Santa Cruz Biotechnology), and CTGF (catalog no. sc-25440, Santa Cruz Biotechnology) at $4{ }^{\circ} \mathrm{C}$ for $16 \mathrm{~h}$ and horseradish peroxidase-conjugated secondary antibodies at room temperature for $1 \mathrm{~h}$. The protein levels were determined using an enhanced chemiluminescence system and a densitometer (UVP, Upland, CA, USA).

\subsection{Immunofluorescence Staining}

Cells placed on cover slides were fixed with $4 \%$ formaldehyde for $10 \mathrm{~min}$ and then incubated with 5\% goat serum for $60 \mathrm{~min}$. Protein levels were determined using primary antibodies against CTGF (catalog no. sc-25440, Santa Cruz Biotechnology) in 5\% bovine serum albumin (BSA) at room temperature for $1 \mathrm{~h}$ and fluorescein isothiocyanate (FITC)-conjugated secondary antibody for another $1 \mathrm{~h}$. Nuclei were counterstained with Hoechst $(1 \mu \mathrm{g} / \mathrm{mL})$. Images were obtained by fluorescent microscopy (OLYMPUS IX 81; Olympus, Tokyo, Japan). 


\subsection{RNA Isolation and Quantitative Real-Time PCR}

Total RNA was extracted from HSCs using TRIzol reagent and $1 \mu \mathrm{g}$ RNA was used as a template for cDNA synthesis by iScript cDNA Synthesis Kit according to the manufacturer's protocol. mRNA levels were determined using Power SYBR Green PCR Master Mix and quantitative PCR with CFX Connect Real-Time PCR Detection System (Bio-Rad, Hercules, CA, USA). Primers for mouse CTGF (5'-GGAATTGTGACCTGAGTGACT-3' and 5'-TGAGCCAGCCATTTCTTAATAAAG-3') and mouse GAPDH (5'-AAGGAGTAAGAAACCCTGGAC-3' and 5'-GATGGAAATTGTGAGGGAGATG-3') were used. The real-time PCR was conducted at $95^{\circ} \mathrm{C}$ for $10 \mathrm{~min}$, followed by 40 cycles of denaturation at $95^{\circ} \mathrm{C}$ for $15 \mathrm{~s}$, and annealing/extension at $60^{\circ} \mathrm{C}$ for $1 \mathrm{~min}$. PCR conditions were optimized to achieve a single peak by melting curve analysis on the CFX Connect system.

\subsection{Determination of Intracellular cGMP Levels}

HSCs were preincubated with ODQ $(1 \mu \mathrm{M})$ and/or indicated phosphodiesterase (PDE) inhibitors for $15 \mathrm{~min}$ and then treated with BAY 41-2272 (0.3-10 $\mu \mathrm{M})$, BAY 63-2521 (0.3-10 $\mu \mathrm{M})$, or BAY 58-2667 $(0.3-10 \mu \mathrm{M})$ in the presences or absence of S-nitroso-N-acetyl penicillamine (SNAP; $0.1 \mu \mathrm{M})$ or sodium nitroprusside (SNP; $0.1 \mu \mathrm{M})$ for another $15 \mathrm{~min}$ at $37^{\circ} \mathrm{C}$. The intracellular cGMP levels were detected using the commercial enzyme immunoassay (EIA) system (catalog no. RPN226, GE Healthcare, Little Chalfont, Buckinghamshire, UK) according to the manufacturer's protocol.

\section{8. sGC Activity Assay}

HSCs were suspended and sonicated in sGC lysis buffer ( $25 \mathrm{mM}$ Tris- $\mathrm{HCl}$ (pH 7.5), $250 \mathrm{mM}$ sucrose, $2 \mathrm{mM}$ EDTA, $5 \mathrm{mM} \mathrm{MgCl}$, $100 \mu \mathrm{M}$ phenylmethylsulfonyl fluoride (PMSF), $10 \mu \mathrm{g} / \mathrm{mL}$ leupeptin, and $10 \mu \mathrm{M}$ pepstain $\mathrm{A})$. After centrifugation at $250 \times g$ for $5 \mathrm{~min}$ at $4{ }^{\circ} \mathrm{C}$, the supernatant was centrifuged at $16,000 \times \mathrm{g}$ for $15 \mathrm{~min}$ at $4{ }^{\circ} \mathrm{C}$. The cytosolic fraction was mixed with the indicated test agents in sGC reaction buffer (25 mM Tris- $\mathrm{HCl}$ ( $\mathrm{pH} 7.5), 15 \mathrm{mM} \mathrm{MgCl}_{2}, 2 \mathrm{mM}$ 3-isobutyl 1-methylxanthine, $15 \mathrm{mM}$ creatine phosphate, 6 units creatine phosphokinase, $2 \mathrm{mM} \mathrm{GTP}$ ) for $20 \mathrm{~min}$ at $30{ }^{\circ} \mathrm{C}$ and then stopped by heating at $100{ }^{\circ} \mathrm{C}$ for $3 \mathrm{~min}$. cGMP levels were measured to determine the sGC activity using a commercial EIA system (catalog no. RPN226, GE Healthcare, Little Chalfont, Buckinghamshire, UK).

\subsection{Statistical Analysis}

Data were expressed as the mean \pm standard error of mean (SD). Statistical comparisons were made between two groups using Student's t-test. $p<0.05$ was considered statistically significant.

\section{Results}

\subsection{BAY 41-2272 sGC Stimulator Inhibited TGFß1-Induced CTGF Expression and Cell Proliferation in Primary HSCs}

To evaluate the biological significance of sGC/cGMP signaling in primary HSCs, we first evaluated the effect of a typical sGC stimulator BAY 41-2272 on TGF $\beta 1$-induced CTGF expression that is a critical pro-fibrotic cytokine for HSC activation. BAY 41-2272 dose-dependently $(1-10 \mu \mathrm{M})$ inhibited the CTGF expression in primary TGF $\beta 1$-activated HSCs, as determined by Western blot and immunofluorescent staining (Figure 1A,B). The TGF $\beta 1$-induced proliferation of primary HSCs was also significantly restricted by BAY 41-2272 (10 $\mu \mathrm{M}$; Figure 1C), suggesting that the compound may serve as an agent to ameliorate HSC activation. 
(A)

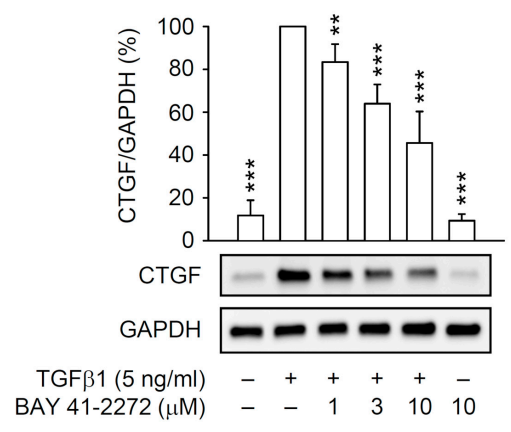

(B)

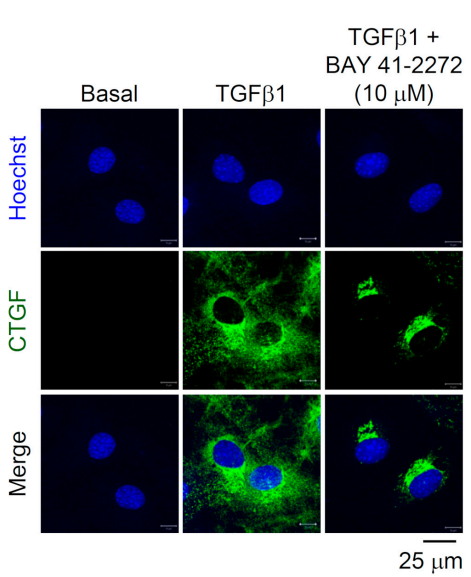

(C)

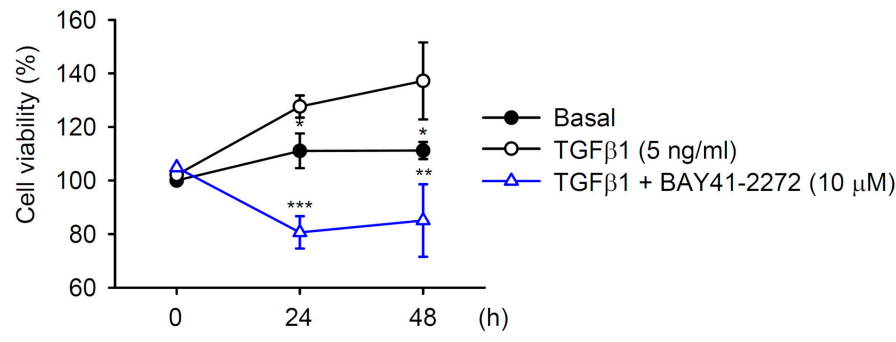

Figure 1. BAY 41-2272 repressed the transforming growth factor (TGF) $\beta 1$-induced connective tissue growth factor (CTGF) expression in hepatic stellate cells (HSCs). HSCs were preincubated with BAY 41-2272 (1-10 $\mu \mathrm{M})$ for $30 \mathrm{~min}$ before activation by TGF $\beta 1(5 \mathrm{ng} / \mathrm{mL})$ for another $(\mathbf{A}, \mathbf{B}) 6 \mathrm{~h}$ or $(\mathbf{C}) 24-48 \mathrm{~h}$. Expression of CTGF and GAPDH was determined by (A) Western blot and (B) immunofluorescent staining using the corresponding antibodies. (C) Cell viability was measured using the WST-1 Assay Kit and monitored spectrophotometrically at $450 \mathrm{~nm}$. All data are expressed as mean $\pm \operatorname{SD}(n=3)$. ${ }^{*} p<0.05,{ }^{* *} p<0.01,{ }^{* * *} p<0.001$ compared with the TGF $\beta 1$ alone.

BAY 41-2272 is a non-NO-based sGC stimulator; two distinctly different NO donors, SNP and SNAP, were used to synergistically enhance sGC/cGMP signaling. A selectively heme-site inhibitor of sGC, ODQ, was also used to examine the molecular actions of BAY 41-2272 in primary HSCs. BAY 41-2272 $(3$ or $10 \mu \mathrm{M})$ increased the intracellular cGMP levels in primary HSCs, and both SNP $(0.1 \mu \mathrm{M})$ and SNAP $(0.1 \mu \mathrm{M})$ synergistically enhanced the BAY 41-2272 $(10 \mu \mathrm{M})$-increased cGMP levels. ODQ blocked all BAY 41-2272 (10 $\mu \mathrm{M})$-induced cGMP production in primary HSCs (Figure 2A). Similarly, BAY 41-2272 $(10 \mu \mathrm{M})$ induced the sGC activity in vitro that was further activated by SNP $(0.1 \mu \mathrm{M})$ or SNAP $(0.1 \mu \mathrm{M})$ and blocked by ODQ $(1 \mu \mathrm{M})$ (Figure $2 \mathrm{~B})$, suggesting that BAY 41-2272 can trigger sGC/cGMP signaling in primary HSCs.

\subsection{The BAY 41-2272-Inhibited CTGF Expression and Cell Proliferation Was not via sGC/cGMP Pathway in TGFB1-Activated Primary HSCS}

To examine whether the inhibitory effects of BAY 41-2272 on HSC activation is through the activated sGC/cGMP signaling, we checked the CTGF expression in TGF $\beta 1$-activated primary HSCs in the presence or absence of inhibitors, ODQ (sGC inhibitor), and KT5823 (cGMP-dependent protein kinase (PKG) inhibitor). Surprisingly, the BAY 41-2272-repressed mRNA and protein expressions of CTGF were not affected by ODQ $(1 \mu \mathrm{M})$ or KT5823 $(3 \mu \mathrm{M})$ in TGF $\beta 1$-activated HSCs (Figure 3$)$. Moreover, the NO donors SNAP $(0.1 \mu \mathrm{M})$ and SNP $(0.1 \mu \mathrm{M})$ did not alter the inhibitory effects of BAY 41-2272 on the TGF $\beta 1$-induced mRNA and protein expression of CTGF in primary HSCs (Figure 4A-C). The BAY 41-2272-repressed cell proliferation was not changed in the presence of SNAP or SNP in 
TGF $\beta 1$-activated primary HSCs (Figure 4D), suggesting that the effects of BAY 41-2272 against HSC activation may be independent on its canonical sGC/cGMP signaling.

(A)

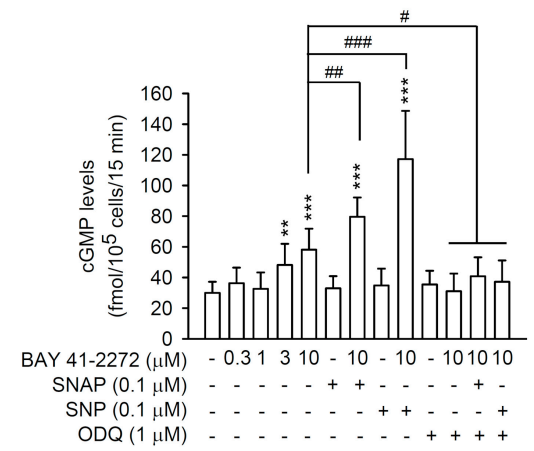

(B)

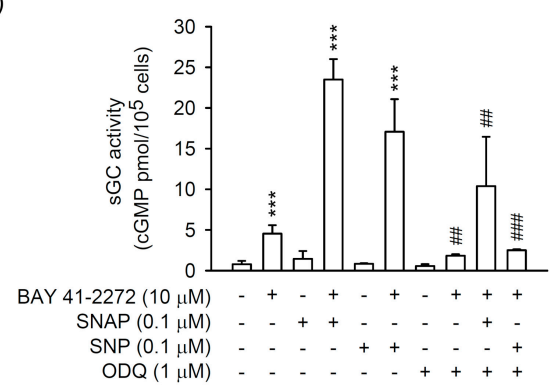

Figure 2. BAY 41-2272 increased the soluble guanylyl cyclase (sGC) activity and cyclic guanosine monophosphate (cGMP) formation in HSCs. (A) HSCs were preincubated with or without ODQ $(1 \mu \mathrm{M})$ sGC inhibitor for $15 \mathrm{~min}$ and then treated with BAY 41-2272 $(0.3-10 \mu \mathrm{M})$ in the presence or absence of S-nitroso-N-acetyl penicillamine (SNAP) $(0.1 \mu \mathrm{M})$ or sodium nitroprusside (SNP) $(0.1 \mu \mathrm{M})$ NO donors for another $15 \mathrm{~min}$. (B) The cytosolic fractions from HSCs were mixed with or without ODQ $(1 \mu \mathrm{M})$, BAY 41-2272 $(10 \mu \mathrm{M})$, SNAP $(0.1 \mu \mathrm{M})$, and/or SNP $(0.1 \mu \mathrm{M})$ at $30{ }^{\circ} \mathrm{C}$ for $20 \mathrm{~min}$. The cGMP levels were assayed using enzyme immunoassay (EIA) kits. All data are expressed as mean \pm SD $(n=4)$. ** $p<0.01,{ }^{* * *} p<0.001$ compared with the basal; ${ }^{*} p<0.05,{ }^{\# \#} p<0.01$, \#\#\# $p<0.001$ compared with (A) BAY 41-2272 $(10 \mu \mathrm{M})$ alone and (B) the corresponding BAY 41-2272 with or without SNAP or SNP.
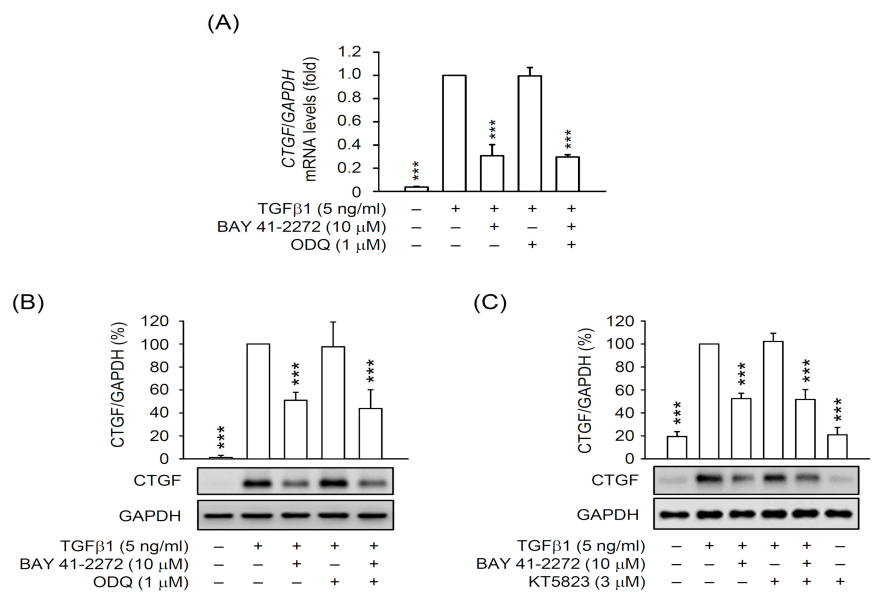

Figure 3. The inhibitory effect of BAY 41-2272 on CTGF expression was independent of the sGC pathway in TGF $\beta 1$-activated HSCs. HSCs were pretreated with or without ODQ $(1 \mu \mathrm{M})$ or KT5823 (cGMP-dependent protein kinase (PKG) inhibitor) $(3 \mu \mathrm{M})$ PKG inhibitors for $15 \mathrm{~min}$. HSCs were sequentially incubated with BAY 41-2272 $(10 \mu \mathrm{M})$ for $30 \mathrm{~min}$ before activation by TGF $\beta 1(5 \mathrm{ng} / \mathrm{mL})$ for another $6 \mathrm{~h}$. (A) mRNA levels of CTGF or GAPDH were determined by quantitative RT-PCR. $(\mathbf{B}, \mathbf{C})$ Expressed CTGF and GAPDH proteins were determined by Western blot using the corresponding antibodies. All data are expressed as mean $\pm \operatorname{SD}(n=3)$. ${ }^{* * *} p<0.001$ compared with the TGF $\beta 1$ alone. 
(A)

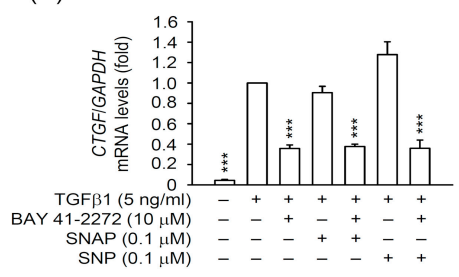

(C)

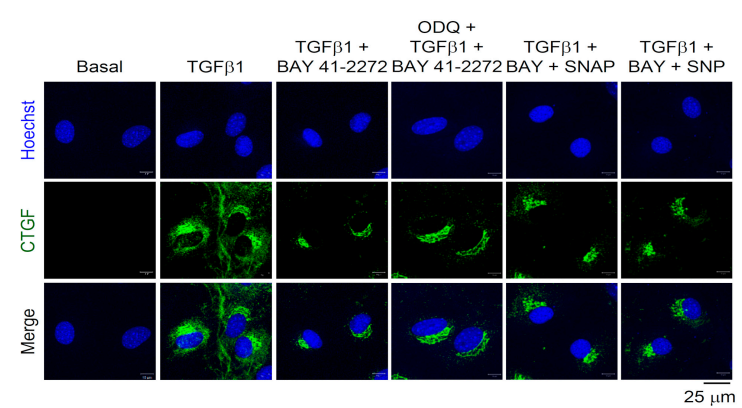

(D)

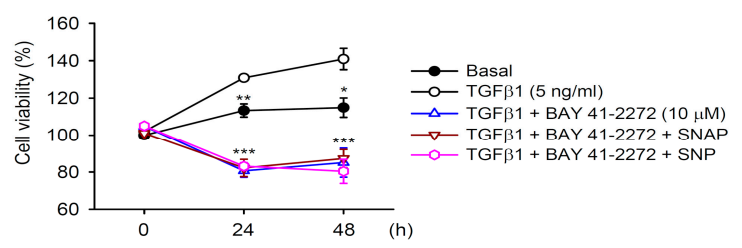

Figure 4. NO donors did not affect the inhibition of TGF $\beta 1$-activated HSCs by BAY 41-2272. HSCs were preincubated with BAY 41-2272 $(10 \mu \mathrm{M})$ in the presence or absence of SNAP $(0.1 \mu \mathrm{M})$ or SNP $(0.1$ $\mu \mathrm{M})$ for $30 \mathrm{~min}$ before activation by TGF $\beta 1(5 \mathrm{ng} / \mathrm{mL})$ for another $(\mathrm{A}-\mathrm{C}) 6 \mathrm{~h}$ or $(\mathbf{D}) 24-48 \mathrm{~h}$. (A) mRNA levels of CTGF and GAPDH were determined by quantitative RT-PCR. (B,C) Expressed CTGF and GAPDH proteins were measured by (B) Western blot and (C) immunofluorescent staining using the corresponding antibodies. (D) Cell viability was measured using the WST-1 assay and monitored spectrophotometrically at $450 \mathrm{~nm}$. All data are expressed as mean $\pm \operatorname{SD}(n=3) .{ }^{*} p<0.05,{ }^{* *} p<0.01$, *** $p<0.001$ compared with the TGF $\beta 1$ alone.

\subsection{PDE9 Modulated the BAY 41-2272-Mediated sGC/cGMP Signaling But not CTGF Inhibition in Primary HSCs}

cGMP-dependent phosphodiesterases (PDEs; PDE1, 2, 3, 5, 6, 9, 10, and 11) are responsible for the conversion from active cGMP to inactive $5^{\prime}$ GMP [33]. To further understand the effect of the sGC/cGMP pathway on HSC activation, we used PDE inhibitors to examine the cGMP production and CTGF expression in primary HSCs. First, the non-specific PDE inhibitor 3-isobutyl-1-methylxanthine (IBMX) apparently increased the BAY 41-2272-induced intracellular cGMP levels in the presence or absence of SNAP or SNP. The cGMP levels were also inhibited by ODQ (Figure 5A). We also screened the isozyme-specific inhibitors of PDEs (vinpocetine for PDE1, erythro-9-(2-hydroxy-3-nonyl)adenine (EHNA) for PDE2, zaprinast and tadalafil for PDE5, BAY 73-6691 for PDE9) to check the BAY 41-2272-induced cGMP production in HSCs. The PDE9 inhibitor BAY 73-6691 showed the strongest effect on increasing the BAY 41-2272-induced cGMP levels (Figure 5B), suggesting that PDE9 is important for the sGC/cGMP pathway in HSCs. However, the PDE9 inhibitor did not change the inhibitory effect of BAY 41-2272 on CTGF expression in TGF $\beta 1$-activated HSCs (Figure 5C). This demonstrates further that the inhibitory effect of BAY 41-2272 on CTGF expression is via the sGC/cGMP-independent pathway. 
(A)

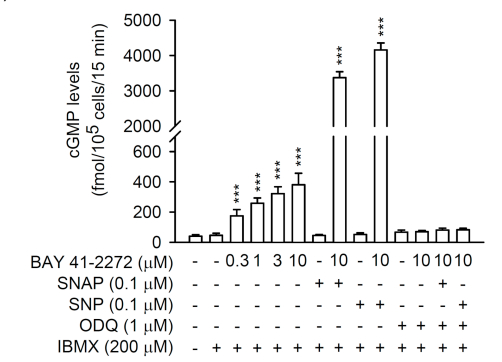

(B)

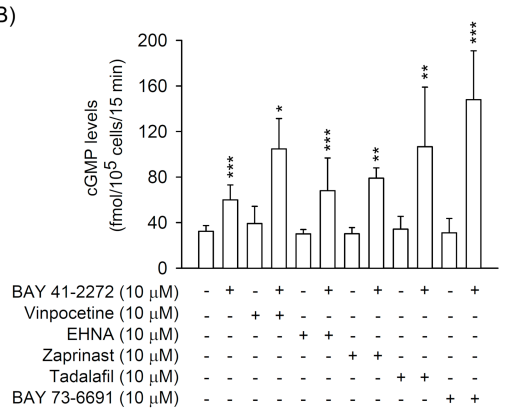

(C)

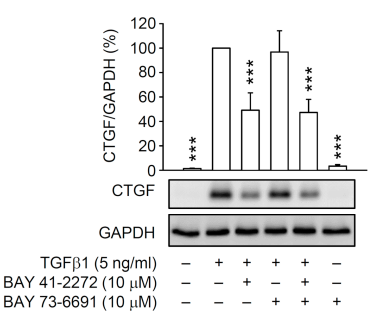

Figure 5. Phosphodiesterase (PDE) inhibitors increase the BAY 41-2272-mediated cGMP formation but not CTGF expression in HSCs. (A,B) HSCs were preincubated with or without (A) IBMX $(200 \mu M)$ and/or ODQ $(1 \mu \mathrm{M})$ or (B) specific PDE inhibitors for $15 \mathrm{~min}$ and then treated with BAY 41-2272 $(0.3-10 \mu \mathrm{M})$ in the presence or absence of SNAP $(0.1 \mu \mathrm{M})$ or SNP $(0.1 \mu \mathrm{M})$ for another $15 \mathrm{~min}$. The cGMP levels were assayed using EIA kits. (C) HSCs were pretreated with or without BAY 73-6691 $(10 \mu \mathrm{M})$ PDE9 inhibitor for $15 \mathrm{~min}$. HSCs were sequentially incubated with BAY 41-2272 (10 $\mu \mathrm{M})$ for $30 \mathrm{~min}$ before activation by TGF $\beta 1(5 \mathrm{ng} / \mathrm{mL})$ for another $6 \mathrm{~h}$. Expressed CTGF and GAPDH were measured by Western blot using the corresponding antibodies. All data are expressed as mean $\pm \mathrm{SD}$ $(n=4) .{ }^{*} p<0.05,{ }^{* *} p<0.01,{ }^{* * *} p<0.001$ compared with the basal $(\mathbf{A}, \mathbf{B})$ or TGF $\beta 1$ alone $(\mathbf{C})$.

\subsection{The TGF $\beta 1$-Induced CTGF Expression is Independent of cGMP Formation in Primary HSCs}

The sGC stimulator BAY 41-2272 has the potential of inhibiting HSC activation by prohibiting CTGF in TGF $\beta 1$-activated primary HSCs; however, this is separate from its ability to elicit sGC activity and cGMP formation. To further characterize the correlation between sGC/cGMP signaling and pro-fibrotic CTGF expression, we used another heme-dependent sGC stimulator, BAY 63-2521, and a heme-independent sGC activator, BAY 58-2667, to analyze the cGMP formation and TGF $\beta 1$-induced CTGF expression in primary HSCs. BAY 63-2521 $(10 \mu \mathrm{M})$ alone increased the intracellular cGMP generation in HSCs that was further increased by synergetic incubation with NO donors SNP $(0.1 \mu \mathrm{M})$ or SNAP $(0.1 \mu \mathrm{M})$. Moreover, the PDE inhibitor IBMX increased the BAY 63-2521-induced cGMP levels in HSCs with or without SNAP or SNP. All the increased cGMP levels were inhibited by ODQ $(1 \mu \mathrm{M})$ (Figure 6A). On the other hand, BAY 58-2667 had no effect on cGMP formation in HSCs, even in the presence of SNAP, SNP, IBMX, and/or ODQ (Figure 6B,C). These results indicate that heme-independent sGC is the major type of sGC in HSCs and may have unique functions in these cells.

BAY 63-2521 and BAY 58-2667 did not affect CTGF expression in TGF $\beta 1$-activated HSCs (Figure 7A,B). An analog of cGMP, 8-Br-cGMP (bromo-cGMP), also did not alter the TGF $\beta 1$-induced CTGF expression in HSCs (Figure 7C), suggesting that cGMP signaling may not be involved in 
CTGF production in TGF $\beta 1$-activated HSCs. Together, the activated sGC/cGMP signaling exhibits no advantage for blocking HSC activation via preventing CTGF expression.

(A)

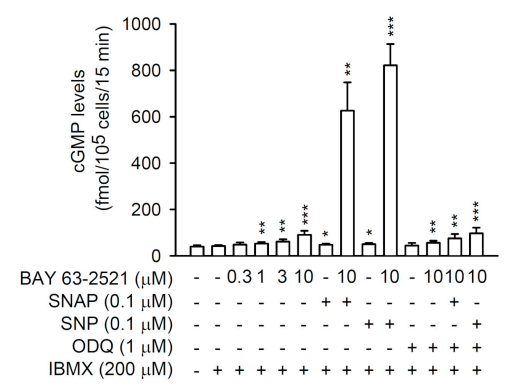

(B)

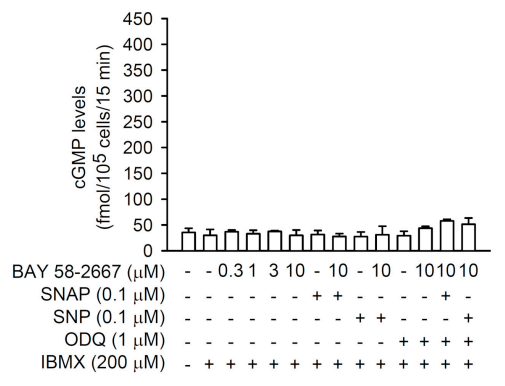

(C)

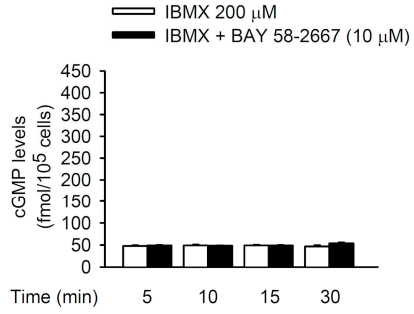

Figure 6. Effects of BAY 63-2521 and BAY 58-2667 on cGMP formation in HSCs. HSCs were preincubated with or without IBMX $(200 \mu \mathrm{M})$ and/or ODQ $(1 \mu \mathrm{M})$ for $15 \mathrm{~min}$ and then treated with (A) BAY 63-2521 $(0.3-10 \mu \mathrm{M})$ or $(\mathbf{B}, \mathbf{C})$ BAY 58-2667 $(0.3-10 \mu \mathrm{M})$ in the presence or absence of SNAP $(0.1 \mu \mathrm{M})$ or SNP $(0.1 \mu \mathrm{M})$ for another $(\mathbf{A}, \mathbf{B}) 15 \mathrm{~min}$ or $(\mathbf{C})$ various time intervals $(5-30 \mathrm{~min})$. The cGMP levels were assayed using EIA kits. All data are expressed as mean $\pm \operatorname{SD}(n=4) .{ }^{*} p<0.05,{ }^{* *} p<0.01,{ }^{* * *} p<0.001$ compared with the basal.

(A)

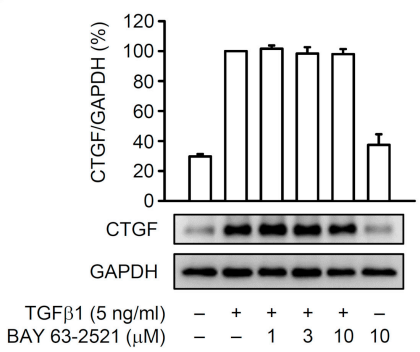

(B)

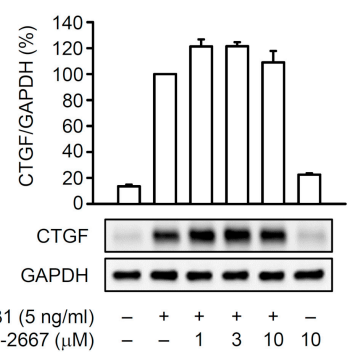

(C)

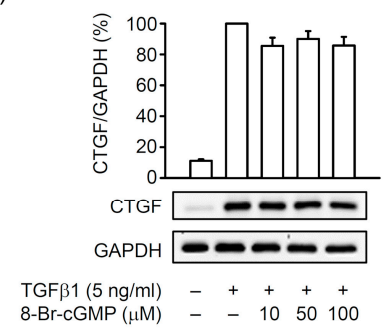

Figure 7. Effects of BAY 63-2521, BAY 58-2667, and 8-Br-cGMP on TGF $\beta 1$-induced CTGF expression in HSCs. HSCs were preincubated with (A) BAY 63-2521 (1-10 $\mu \mathrm{M}),($ B) BAY 58-2667 $(1-10 \mu \mathrm{M})$, or (C) 8-Br-cGMP $(10-100 \mu \mathrm{M})$ for $30 \mathrm{~min}$ before activation by TGF $\beta 1(5 \mathrm{ng} / \mathrm{mL})$ for another $6 \mathrm{~h}$. Expressed CTGF and GAPDH were determined by Western blot using the corresponding antibodies. All data are expressed as mean $\pm \mathrm{SD}(n=3)$. 


\subsection{BAY 41-2272 Selectively Inhibited the TGF $\beta 1-I n d u c e d$ Akt Activation in Primary HSCs}

The TGF $\beta$-activated Smad and non-Smad pathways have been well-documented as the predominant fibrotic signaling in HSCs during liver fibrosis [16,17]. We checked the effect of BAY 41-2272 on Smad2/3 and Akt phosphorylation in TGF 31 -activated HSCs to investigate its downstream signaling. TGF $\beta 1$ (5 ng/mL) significantly triggered the phosphorylation of Smad2, Smad3, and Akt within $20 \mathrm{~min}$, and BAY 41-2272 (10 $\mu \mathrm{M})$ selectively reduced the TGF $\beta 1$-activated Akt but not Smad2/3 in primary HSCs (Figure 8A,B). The sGC inhibitor ODQ $(1 \mu \mathrm{M})$ did not affect BAY 41-2272-inhibited Akt activation in TGF $\beta 1$-activated HSCs (Figure 8C), suggesting that the inhibitory effect of BAY 41-2272 may be mediated through Akt instead of the sGC/cGMP and Smad pathway in HSCs. Inhibition of phosphoinositide 3-kinase (PI3K) signaling in HSCs attenuates liver fibrosis [34,35]. Similarly, LY294002 PI3K inhibitor dose-dependently (1-10 $\mu \mathrm{M})$ attenuated the Akt phosphorylation, CTGF expression, and cell viability in TGF $\beta 1$-activated primary HSCs (Figure 8D,E). During HSC activation, BAY 41-2272-based restriction of TGF $\beta 1$-induced CTGF expression may be selectively modulated through Akt-dependent but sGC/cGMP- and Smad-independent pathway.

(A)

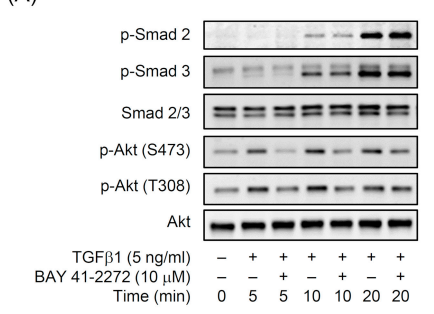

(C)

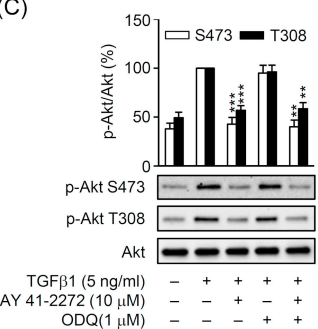

ODQ(1 $\mu \mathrm{M})$

(B)

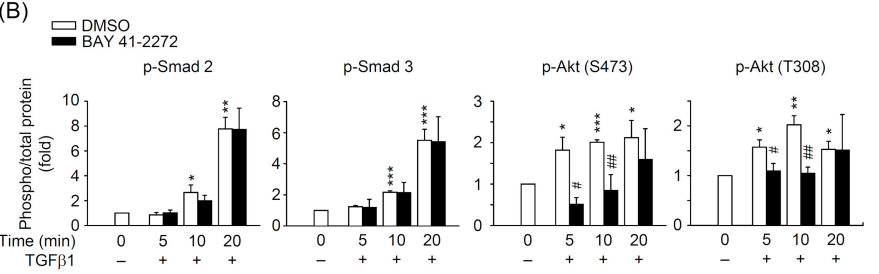

(D)

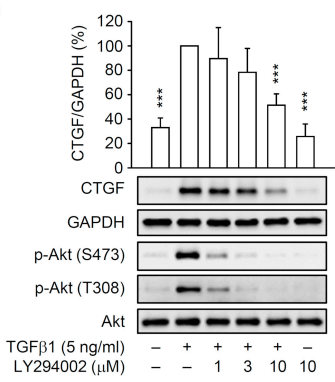

(E)

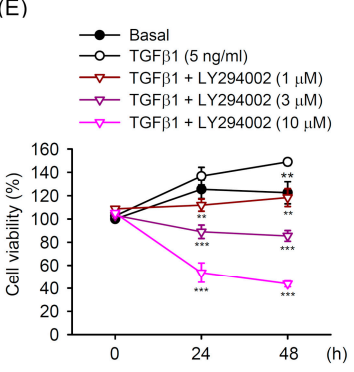

Figure 8. The BAY 41-2272-inhibited CTGF expression was dependent on Akt signaling in TGF $\beta 1$-activated HSCs. HSCs were pretreated with or without ODQ $(1 \mu \mathrm{M})$ for $15 \mathrm{~min}$. HSCs were sequentially incubated with (A-C) BAY 41-2272 $(10 \mu \mathrm{M})$ or $(\mathbf{D}, \mathrm{E})$ LY294002 $(1-10 \mu \mathrm{M})$ Akt signaling inhibitor for $30 \mathrm{~min}$ before activation by TGF $\beta 1(5 \mathrm{ng} / \mathrm{mL})$ for another $(\mathbf{A}, \mathbf{B}) 5-20 \mathrm{~min}$, (C,D) $10 \mathrm{~min}$, or (E) 24-48 h. (A-D) Protein levels were determined by Western blot using antibodies against p-Smad2, p-Smad3, Smad2/3, p-Akt (S473 or T308), Akt, CTGF, or GAPDH. (E) Cell viability was measured using the WST-1 assay and monitored spectrophotometrically at $450 \mathrm{~nm}$. All data are expressed as mean $\pm \mathrm{SD}(n=3)$. ${ }^{*} p<0.05,{ }^{* *} p<0.01,{ }^{* * *} p<0.001$ compared with the basal (B) or TGF $\beta 1$ alone (C-E). ${ }^{\#} p<0.05,{ }^{\# \#} p<0.01$ compared with the corresponding DMSO group.

\section{Discussion}

The fibrogenic cytokines TGF $\beta$ and CTGF trigger HSC activation as a pathogenic factor during liver fibrosis. Emerging evidence shows that stopping TGF $\beta$-CTGF upregulation and sGC modulators 
are effective ways to control HSC activation [11,16,20,23]; however, the full understanding of their correlation is still elusive. BAY 41-2272 is a well-described sGC stimulator that is used to ameliorate fibrotic lesion [24-29], but its application in HSC remains undefined. In the present study, we manifested the pharmacological effects and mechanisms of BAY 41-2272 and sGC/cGMP signaling in TGF $\beta$-activated primary mouse HSCs. BAY 41-2272 remarkably restricted the TGF $\beta 1$-induced CTGF upregulation and cell proliferation in mouse primary HSCs, along with increased cGMP levels and sGC activity. However, the inhibitory effects of BAY 41-2272 on TGF $\beta 1$-induced HSC activation and induction of sGC/cGMP signaling are astonishingly unconnected. BAY 41-2272 restricted the Akt activation instead of canonical Smad2/3 pathway in TGF $\beta 1$-activated HSCs, providing a plausible cellular basis for the mechanistic actions of BAY 41-2272 and Akt for HSC activation.

A growing body of evidence indicates that reversing to quiescent status or preventing proliferation is an effective way to treat activated HSCs $[4,36,37]$. TGF $\beta$ has been well-established for inducing HSCs into an activated status and becoming, in turn, myofibroblast-like cells with proliferative, contractile, and fibrogenic properties [16-18]. TGF $\beta$ signaling upregulates another fibrogenic factor, CTGF, which contributes to HSC activation [20,38,39]; inhibition of CTGF is an option for attenuating HSC activation [40-42]. In this study, we used isolated primary HSCs to address the possibility of targeting TGF $\beta 1$-induced CTGF expression. Both RNA and protein levels of CTGF are upregulated in TGF $\beta 1$-activated HSCs and hence the inhibitory effects of BAY 41-2272 on CTGF upregulation and HSC proliferation should be relevant to its anti-fibrotic effect on HSC activation (Figures 1 and 3). Therefore, targeting CTGF upregulation may be an effective way of attenuating TGF $\beta$-induced HSC activation.

The NO/sGC/cGMP pathway maintains various physiological homeostasis, and induction of sGC/cGMP signaling has been proposed to inhibit fibrogenesis [11,43]. However, the role of NO in regulating HSCs remains controversial. For example, the nitrovasodilator-mediated contraction and proliferation of HSCs are both NO/cGMP-dependent and -independent [14,44,45]. Lipopolysaccharide (LPS) triggers HSC s to release NO, but this is not related to HSC-induced hepatocyte proliferation [46,47]. Moreover, release of NO inhibits HSC activation [48]. Therefore, NO signaling may show diverse functions during HSC activation. SNP and SNAP act as NO donors via enzymatic oxidation and chemical reaction, respectively [49]. Both SNP and SNAP synergistically potentiated the BAY 41-2272-induced sGC activities and cGMP levels in HSCs (Figure 2); however, SNP and SNAP did not affect the BAY 41-2272-inhibited CTGF upregulation and proliferation of HSCs (Figure 4). We suggest that NO production may not participate in TGF $\beta 1$-induced HSC activation, although it augments sGC/cGMP signaling.

sGCs are expressed in HSCs and not in hepatocytes [50] and are divided into reduced and oxidized forms that possess heme-dependent and heme-independent properties, respectively [11,13]. Many sGC modulators have been developed: (1) sGC stimulators to sensitize the reduced and heme-containing sGC to NO, and (2) sGC activators to activate oxidized and heme-free sGC [51-53] to generate cGMP. Exposure of 8-Br-cGMP cGMP analog leads to an inhibition of TGF $\beta$-induced fibrogenesis in renal, cardiac, and dermal fibroblasts $[26,54,55]$, suggesting that the sGC/cGMP pathway may be preferential signaling for TGF $\beta$-induced HSC activation. Here, the BAY 41-2272 sGC stimulator showed potent inducible and inhibitory effects on cGMP levels and TGF $\beta 1$-increased CTGF expression in HSCs (Figures 1 and 2). However, only increased cGMP levels and sGC activity but not decreased CTGF expression was reversed by the ODQ sGC inhibitor in BAY 41-2272-treated HSCs (Figures 2 and 3). Importantly, the elevation of cGMP signaling by KT5823 (PKG inhibitor), BAY 73-6691 (PDE9 inhibitor), and 8-Br-cGMP (cGMP analog) failed to alter the TGF 31 -induced CTGF expression in HSCs (Figure 3C, Figure $5 \mathrm{C}$, and Figure $7 \mathrm{C}$ ). Together, our results may support the existence of a unique framework making TGF $\beta$-based HSC activation independent of sGC/cGMP signaling.

Emerging evidence has indicated the potential application of sGC modulators for treating a fibrotic lesion in the liver, skin, lung, and kidneys [11,15]. Riociguat (BAY 63-2521) is an sGC stimulator used for treating pulmonary hypertension that has attenuated cholestatic fibrogenesis and cirrhotic portal hypertension in rats [56,57]. IW-1973 and praliciguat sGC stimulators prevented hepatic fibrosis 
in models of non-alcoholic steatohepatitis [51,58]. Oral administration of BAY 60-2770 sGC activator prevented the carbon tetrachloride-induced hepatic fibrous collagen formation in rats [59]. Noticeably, BAY 41-2272 can quell fibrogenesis in various fibrotic disorders [24-29]; however, its effects on liver fibrosis is limited. In the present study, we evaluated the effects of BAY 41-2272 and BAY 63-2521 sGC stimulators, and BAY 58-2667 sGC activator on TGF $\beta 1$-mediated HSC activation. Only BAY 41-2272 inhibited the TGF 31 -induced CTGF expression in primary HSCs (Figure 1). BAY 63-2521 that synergistically increased cGMP levels with NO donors and BAY 58-2667 failed to alter the CTGF upregulation in TGF $\beta 1$-activated HSCs (Figures 6 and 7). We propose that BAY 41-2272 may be distinct from other sGC modulators and exhibits two diverse pathways in HSCs: (1) canonical $\mathrm{NO} / \mathrm{sGC} / \mathrm{cGMP}$-dependent signaling for undefined functions, and (2) sGC-independent repression of TGF $\beta 1$-triggered HSC activation.

In general, TGF $\beta$ binding with the TGF $\beta$ receptor leads to phosphorylation of the receptor-activated Smad2 and Smad3. Additionally, non-canonical Smad-independent signaling pathways such as PI3K/Akt are activated by TGF $\beta$ and provide a broad TGF $\beta$-induced intracellular crosstalk $[18,19]$. Targeting PI3K/Akt signaling also restrains the progression of HSC activation, including cell proliferation and CTGF expression [34,35,60-62], supporting the biological significance of the PI3K/Akt pathway for TGF $\beta$-dependent HSC activation. In this study, BAY 41-2272 reduced the TGF $\beta 1$-induced phosphorylation of Akt but not canonical Smad2/3. Pharmacological inhibition of PI3K/Akt also apparently blocked the TGF $\beta 1$-induced CTGF expression and proliferation of HSCs (Figure 8). Because the effect of BAY 41-2272 on Akt phosphorylation was transient, we cannot exclude the possibility that the inhibitory effects of BAY 41-2272 in HSCs are mediated by other targets. This is the first time that BAY 41-2272 was explored to treat TGF $\beta$-mediated HSC activation via targeting the PI3K/Akt that plays an important role in this process.

\section{Conclusions}

We illustrate that the BAY 41-2272 sGC stimulator attenuates the TGF $\beta 1$-induced CTGF expression and cell proliferation through the Akt signaling and not the sGC/cGMP pathway in mouse primary HSCs. Our results provide a novel insight into the TGF $\beta 1$ - and BAY 41-2272-based regulatory networks and molecular profiles for HSC activation.

Author Contributions: P.-J.C., L.-M.K., Y.-H.W., Y.-C.C., and K.-H.L. designed and performed the experiments and analyzed the data. P.-J.C. and T.-L.H. wrote and completed the manuscript. T.-L.H. supervised the entire study. All authors have read and agreed to the published version of the manuscript.

Funding: This research was funded by the Chang Gung Medical Research Foundation (BMRP450, CMRPG6J0141-3, CMRPF1G0241-3, and CMRPF1J0051-3), and the Ministry of Science and Technology (MOST 109-2320-B-126-003-MY3, MOST 106-2320-B-255-003-MY3, MOST 108-2320-B-255-003-MY3, MOST 108-2320-B-126-001, and MOST 107-2320-B-182A-004-MY2), Taiwan.

Conflicts of Interest: The authors declare no conflict of interest. The funders had no role in the design of the study; in the collection, analyses, or interpretation of data; in the writing of the manuscript, or in the decision to publish the results.

\section{References}

1. Tsuchida, T.; Friedman, S.L. Mechanisms of hepatic stellate cell activation. Nat. Rev. Gastroenterol. Hepatol. 2017, 14, 397-411. [CrossRef] [PubMed]

2. Cai, X.; Wang, J.; Wang, J.; Zhou, Q.; Yang, B.; He, Q.; Weng, Q. Intercellular crosstalk of hepatic stellate cells in liver fibrosis: New insights into therapy. Pharmacol. Res. 2020, 155, 104720. [CrossRef] [PubMed]

3. Khomich, O.; Ivanov, A.V.; Bartosch, B. Metabolic Hallmarks of Hepatic Stellate Cells in Liver Fibrosis. Cells 2019, 9, 24. [CrossRef] [PubMed]

4. Huang, Y.; Deng, X.; Liang, J. Modulation of hepatic stellate cells and reversibility of hepatic fibrosis. Exp. Cell Res. 2017, 352, 420-426. [CrossRef]

5. Higashi, T.; Friedman, S.L.; Hoshida, Y. Hepatic stellate cells as key target in liver fibrosis. Adv. Drug Deliv. Rev. 2017, 121, 27-42. [CrossRef] 
6. Kuo, L.M.; Chen, P.J.; Sung, P.J.; Chang, Y.C.; Ho, C.T.; Wu, Y.H.; Hwang, T.L. The Bioactive Extract of Pinnigorgia sp. Induces Apoptosis of Hepatic Stellate Cells via ROS-ERK/JNK-Caspase-3 Signaling. Mar. Drugs 2018, 16, 19. [CrossRef]

7. Schuppan, D.; Ashfaq-Khan, M.; Yang, A.T.; Kim, Y.O. Liver fibrosis: Direct antifibrotic agents and targeted therapies. Matrix Biol. 2018, 68-69, 435-451. [CrossRef]

8. Evgenov, O.V.; Pacher, P.; Schmidt, P.M.; Hasko, G.; Schmidt, H.H.; Stasch, J.P. NO-independent stimulators and activators of soluble guanylate cyclase: Discovery and therapeutic potential. Nature reviews. Drug Discov. 2006, 5, 755-768. [CrossRef]

9. Wobst, J.; Kessler, T.; Dang, T.A.; Erdmann, J.; Schunkert, H. Role of sGC-dependent NO signalling and myocardial infarction risk. J. Mol. Med. 2015, 93, 383-394. [CrossRef]

10. Hollas, M.A.; Ben Aissa, M.; Lee, S.H.; Gordon-Blake, J.M.; Thatcher, G.R.J. Pharmacological manipulation of cGMP and NO/cGMP in CNS drug discovery. Nitric Oxide 2019, 82, 59-74. [CrossRef]

11. Hu, L.; Wang, Z.; Yi, R.; Yi, H.; Xiao, S.; Chen, Z.; Hu, G.; Li, Q. Soluble Guanylate Cyclase: A New Therapeutic Target for Fibrotic Diseases. Curr. Med. Chem. 2017, 24, 3203-3215. [CrossRef] [PubMed]

12. Priviero, F.B.; Webb, R.C. Heme-dependent and independent soluble guanylate cyclase activators and vasodilation. J. Cardiovasc. Pharmacol. 2010, 56, 229-233. [CrossRef] [PubMed]

13. Xiao, S.; Li, Q.; Hu, L.; Yu, Z.; Yang, J.; Chang, Q.; Chen, Z.; Hu, G. Soluble Guanylate Cyclase Stimulators and Activators: Where are We and Where to Go? Mini Rev. Med. Chem. 2019, 19, 1544-1557. [CrossRef] [PubMed]

14. Perri, R.E.; Langer, D.A.; Chatterjee, S.; Gibbons, S.J.; Gadgil, J.; Cao, S.; Farrugia, G.; Shah, V.H. Defects in cGMP-PKG pathway contribute to impaired NO-dependent responses in hepatic stellate cells upon activation. Am. J. Physiol. Gastrointest. Liver Physiol. 2006, 290, G535-G542. [CrossRef]

15. Sandner, P.; Stasch, J.P. Anti-fibrotic effects of soluble guanylate cyclase stimulators and activators: A review of the preclinical evidence. Respir. Med. 2017, 122 (Suppl. S1), S1-S9. [CrossRef]

16. Dewidar, B.; Meyer, C.; Dooley, S.; Meindl-Beinker, A.N. TGF-beta in Hepatic Stellate Cell Activation and Liver Fibrogenesis-Updated 2019. Cells 2019, 8, 1419. [CrossRef]

17. Fabregat, I.; Caballero-Diaz, D. Transforming Growth Factor-beta-Induced Cell Plasticity in Liver Fibrosis and Hepatocarcinogenesis. Front. Oncol. 2018, 8, 357. [CrossRef]

18. Fabregat, I.; Moreno-Caceres, J.; Sanchez, A.; Dooley, S.; Dewidar, B.; Giannelli, G.; Ten Dijke, P.; Consortium, I.-L. TGF-beta signalling and liver disease. FEBS J. 2016, 283, 2219-2232. [CrossRef]

19. Carthy, J.M. TGFbeta signaling and the control of myofibroblast differentiation: Implications for chronic inflammatory disorders. J. Cell. Physiol. 2018, 233, 98-106. [CrossRef]

20. Liu, Y.; Liu, H.; Meyer, C.; Li, J.; Nadalin, S.; Konigsrainer, A.; Weng, H.; Dooley, S.; ten Dijke, P. Transforming growth factor-beta (TGF-beta)-mediated connective tissue growth factor (CTGF) expression in hepatic stellate cells requires Stat3 signaling activation. J. Biol. Chem. 2013, 288, 30708-30719. [CrossRef]

21. Colak, Y.; Senates, E.; Coskunpinar, E.; Oltulu, Y.M.; Zemheri, E.; Ozturk, O.; Doganay, L.; Mesci, B.; Yilmaz, Y.; Enc, F.Y.; et al. Concentrations of connective tissue growth factor in patients with nonalcoholic fatty liver disease: Association with liver fibrosis. Dis. Markers 2012, 33, 77-83. [CrossRef]

22. Ramazani, Y.; Knops, N.; Elmonem, M.A.; Nguyen, T.Q.; Arcolino, F.O.; van den Heuvel, L.; Levtchenko, E.; Kuypers, D.; Goldschmeding, R. Connective tissue growth factor (CTGF) from basics to clinics. Matrix Biol. 2018, 68-69, 44-66. [CrossRef]

23. Huang, G.; Brigstock, D.R. Regulation of hepatic stellate cells by connective tissue growth factor. Front. Biosci. 2012, 17, 2495-2507.

24. Wang, Y.; Kramer, S.; Loof, T.; Martini, S.; Kron, S.; Kawachi, H.; Shimizu, F.; Neumayer, H.H.; Peters, H. Enhancing cGMP in experimental progressive renal fibrosis: Soluble guanylate cyclase stimulation vs. phosphodiesterase inhibition. Am. J. Physiol. Ren. Physiol. 2006, 290, F167-F176. [CrossRef] [PubMed]

25. Masuyama, H.; Tsuruda, T.; Sekita, Y.; Hatakeyama, K.; Imamura, T.; Kato, J.; Asada, Y.; Stasch, J.P.; Kitamura, K. Pressure-independent effects of pharmacological stimulation of soluble guanylate cyclase on fibrosis in pressure-overloaded rat heart. Hypertens. Res. 2009, 32, 597-603. [CrossRef] [PubMed]

26. Beyer, C.; Zenzmaier, C.; Palumbo-Zerr, K.; Mancuso, R.; Distler, A.; Dees, C.; Zerr, P.; Huang, J.; Maier, C.; Pachowsky, M.L.; et al. Stimulation of the soluble guanylate cyclase (sGC) inhibits fibrosis by blocking non-canonical TGFbeta signalling. Ann. Rheum. Dis. 2015, 74, 1408-1416. [CrossRef]

27. Kadoya, H.; Satoh, M.; Nagasu, H.; Sasaki, T.; Kashihara, N. Deficiency of endothelial nitric oxide signaling pathway exacerbates peritoneal fibrosis in mice. Clin. Exp. Nephrol. 2015, 19, 567-575. [CrossRef] 
28. Matei, A.E.; Beyer, C.; Gyorfi, A.H.; Soare, A.; Chen, C.W.; Dees, C.; Bergmann, C.; Ramming, A.; Friebe, A.; Hofmann, F.; et al. Protein kinases G are essential downstream mediators of the antifibrotic effects of sGC stimulators. Ann. Rheum. Dis. 2018, 77, 459. [CrossRef]

29. Lambers, C.; Boehm, P.M.; Karabacak, Y.; Samaha, E.; Benazzo, A.; Jaksch, P.; Roth, M. Combined Activation of Guanylate Cyclase and Cyclic AMP in Lung Fibroblasts as a Novel Therapeutic Concept for Lung Fibrosis. Biomed Res. Int. 2019, 2019. [CrossRef]

30. Chen, C.H.; Kuo, L.M.; Chang, Y.; Wu, W.; Goldbach, C.; Ross, M.A.; Stolz, D.B.; Chen, L.; Fung, J.J.; Lu, L.; et al. In Vivo immune modulatory activity of hepatic stellate cells in mice. Hepatology 2006, 44, 1171-1181. [CrossRef]

31. Yu, M.C.; Chen, C.H.; Liang, X.; Wang, L.; Gandhi, C.R.; Fung, J.J.; Lu, L.; Qian, S. Inhibition of T-cell responses by hepatic stellate cells via B7-H1-mediated T-cell apoptosis in mice. Hepatology 2004, 40, 1312-1321. [CrossRef] [PubMed]

32. Liu, C.; Gaca, M.D.; Swenson, E.S.; Vellucci, V.F.; Reiss, M.; Wells, R.G. Smads 2 and 3 are differentially activated by transforming growth factor-beta (TGF-beta) in quiescent and activated hepatic stellate cells. Constitutive nuclear localization of Smads in activated cells is TGF-beta-independent. J. Biol. Chem. 2003, 278, 11721-11728. [CrossRef] [PubMed]

33. Lugnier, C.; Meyer, A.; Talha, S.; Geny, B. Cyclic nucleotide phosphodiesterases: New targets in the metabolic syndrome? Pharmacol. Ther. 2020, 208, 107475. [CrossRef] [PubMed]

34. Son, G.; Hines, I.N.; Lindquist, J.; Schrum, L.W.; Rippe, R.A. Inhibition of phosphatidylinositol 3-kinase signaling in hepatic stellate cells blocks the progression of hepatic fibrosis. Hepatology 2009, 50, 1512-1523. [CrossRef] [PubMed]

35. Son, M.K.; Ryu, Y.L.; Jung, K.H.; Lee, H.; Lee, H.S.; Yan, H.H.; Park, H.J.; Ryu, J.K.; Suh, J.K.; Hong, S.; et al. HS-173, a novel PI3K inhibitor, attenuates the activation of hepatic stellate cells in liver fibrosis. Sci. Rep. 2013, 3, 3470. [CrossRef] [PubMed]

36. Jia, Y.; Wang, F.; Guo, Q.; Li, M.; Wang, L.; Zhang, Z.; Jiang, S.; Jin, H.; Chen, A.; Tan, S.; et al. Curcumol induces RIPK1/RIPK3 complex-dependent necroptosis via JNK1/2-ROS signaling in hepatic stellate cells. Redox Biol. 2018, 19, 375-387. [CrossRef] [PubMed]

37. Zhang, C.Y.; Yuan, W.G.; He, P.; Lei, J.H.; Wang, C.X. Liver fibrosis and hepatic stellate cells: Etiology, pathological hallmarks and therapeutic targets. World J. Gastroenterol. 2016, 22, 10512-10522. [CrossRef]

38. Gao, R.; Brigstock, D.R. Connective tissue growth factor (CCN2) induces adhesion of rat activated hepatic stellate cells by binding of its C-terminal domain to integrin alpha(v)beta(3) and heparan sulfate proteoglycan. J. Biol. Chem. 2004, 279, 8848-8855. [CrossRef]

39. Chen, L.; Charrier, A.L.; Leask, A.; French, S.W.; Brigstock, D.R. Ethanol-stimulated differentiated functions of human or mouse hepatic stellate cells are mediated by connective tissue growth factor. J. Hepatol. 2011, 55, 399-406. [CrossRef]

40. Seo, H.Y.; Lee, S.H.; Lee, J.H.; Kang, Y.N.; Hwang, J.S.; Park, K.G.; Kim, M.K.; Jang, B.K. Src Inhibition Attenuates Liver Fibrosis by Preventing Hepatic Stellate Cell Activation and Decreasing Connetive Tissue Growth Factor. Cells 2020, 9, 558. [CrossRef]

41. Chen, A.; Zheng, S. Curcumin inhibits connective tissue growth factor gene expression in activated hepatic stellate cells in vitro by blocking NF-kappaB and ERK signalling. Br. J. Pharmacol. 2008, 153, 557-567. [CrossRef] [PubMed]

42. Hao, C.; Xie, Y.; Peng, M.; Ma, L.; Zhou, Y.; Zhang, Y.; Kang, W.; Wang, J.; Bai, X.; Wang, P.; et al. Inhibition of connective tissue growth factor suppresses hepatic stellate cell activation In Vitro and prevents liver fibrosis In Vivo. Clin. Exp. Med. 2014, 14, 141-150. [CrossRef] [PubMed]

43. Sandner, P.; Berger, P.; Zenzmaier, C. The Potential of sGC Modulators for the Treatment of Age-Related Fibrosis: A Mini-Review. Gerontology 2017, 63, 216-227. [CrossRef] [PubMed]

44. Kawada, N.; Kuroki, T.; Uoya, M.; Inoue, M.; Kobayashi, K. Smooth muscle alpha-actin expression in rat hepatic stellate cell is regulated by nitric oxide and cGMP production. Biochem. Biophys. Res. Commun. 1996, 229, 238-242. [CrossRef] [PubMed]

45. Failli, P.; De, F.R.; Caligiuri, A.; Gentilini, A.; Romanelli, R.G.; Marra, F.; Batignani, G.; Guerra, C.T.; Laffi, G.; Gentilini, P.; et al. Nitrovasodilators inhibit platelet-derived growth factor-induced proliferation and migration of activated human hepatic stellate cells. Gastroenterology 2000, 119, 479-492. [CrossRef] 
46. Thirunavukkarasu, C.; Watkins, S.C.; Gandhi, C.R. Mechanisms of endotoxin-induced NO, IL-6, and TNF-alpha production in activated rat hepatic stellate cells: Role of p38 MAPK. Hepatology 2006, 44, 389-398. [CrossRef]

47. Uemura, T.; Gandhi, C.R. Inhibition of DNA synthesis in cultured hepatocytes by endotoxin-conditioned medium of activated stellate cells is transforming growth factor-beta and nitric oxide-independent. $\mathrm{Br}$. J. Pharmacol. 2001, 133, 1125-1133. [CrossRef]

48. Urtasun, R.; Cubero, F.J.; Vera, M.; Nieto, N. Reactive nitrogen species switch on early extracellular matrix remodeling via induction of MMP1 and TNFalpha. Gastroenterology 2009, 136, 1410-1422. [CrossRef]

49. Wang, P.G.; Xian, M.; Tang, X.; Wu, X.; Wen, Z.; Cai, T.; Janczuk, A.J. Nitric oxide donors: Chemical activities and biological applications. Chem. Rev. 2002, 102, 1091-1134. [CrossRef]

50. Hall, K.C.; Bernier, S.G.; Jacobson, S.; Liu, G.; Zhang, P.Y.; Sarno, R.; Catanzano, V.; Currie, M.G.; Masferrer, J.L. sGC stimulator praliciguat suppresses stellate cell fibrotic transformation and inhibits fibrosis and inflammation in models of NASH. Proc. Natl. Acad. Sci. USA 2019, 116, 11057-11062. [CrossRef]

51. Hwang, T.L.; Tang, M.C.; Kuo, L.M.; Chang, W.D.; Chung, P.J.; Chang, Y.W.; Fang, Y.C. YC-1 potentiates cAMP-induced CREB activation and nitric oxide production in alveolar macrophages. Toxicol. Appl. Pharmacol. 2012, 260, 193-200. [CrossRef] [PubMed]

52. Breitenstein, S.; Roessig, L.; Sandner, P.; Lewis, K.S. Novel sGC Stimulators and sGC Activators for the Treatment of Heart Failure. Handb. Exp. Pharmacol. 2017, 243, 225-247. [CrossRef] [PubMed]

53. Sandner, P.; Zimmer, D.P.; Milne, G.T.; Follmann, M.; Hobbs, A.; Stasch, J.P. Soluble Guanylate Cyclase Stimulators and Activators. Handb. Exp. Pharmacol. 2019. [CrossRef]

54. Abdelaziz, N.; Colombo, F.; Mercier, I.; Calderone, A. Nitric oxide attenuates the expression of transforming growth factor-beta(3) mRNA in rat cardiac fibroblasts via destabilization. Hypertension 2001, 38, 261-266. [CrossRef] [PubMed]

55. Hewitson, T.D.; Martic, M.; Darby, I.A.; Kelynack, K.J.; Bisucci, T.; Tait, M.G.; Becker, G.J. Intracellular cyclic nucleotide analogues inhibit in vitro mitogenesis and activation of fibroblasts derived from obstructed rat kidneys. Nephron. Exp. Nephrol. 2004, 96, e59-e66. [CrossRef]

56. Frey, R.; Becker, C.; Saleh, S.; Unger, S.; van der Mey, D.; Muck, W. Clinical Pharmacokinetic and Pharmacodynamic Profile of Riociguat. Clin. Pharmacokinet. 2018, 57, 647-661. [CrossRef]

57. Schwabl, P.; Brusilovskaya, K.; Supper, P.; Bauer, D.; Konigshofer, P.; Riedl, F.; Hayden, H.; Fuchs, C.D.; Stift, J.; Oberhuber, G.; et al. The soluble guanylate cyclase stimulator riociguat reduces fibrogenesis and portal pressure in cirrhotic rats. Sci. Rep. 2018, 8, 9372. [CrossRef]

58. Flores-Costa, R.; Alcaraz-Quiles, J.; Titos, E.; Lopez-Vicario, C.; Casulleras, M.; Duran-Guell, M.; Rius, B.; Diaz, A.; Hall, K.; Shea, C.; et al. The soluble guanylate cyclase stimulator IW-1973 prevents inflammation and fibrosis in experimental non-alcoholic steatohepatitis. Br. J. Pharmacol. 2018, 175, 953-967. [CrossRef]

59. Knorr, A.; Hirth-Dietrich, C.; Alonso-Alija, C.; Harter, M.; Hahn, M.; Keim, Y.; Wunder, F.; Stasch, J.P. Nitric oxide-independent activation of soluble guanylate cyclase by BAY 60-2770 in experimental liver fibrosis. Arzneimittel-Forschung 2008, 58, 71-80. [CrossRef]

60. Lei, Y.; Wang, Q.L.; Shen, L.; Tao, Y.Y.; Liu, C.H. MicroRNA-101 suppresses liver fibrosis by downregulating PI3K/Akt/mTOR signaling pathway. Clin. Res. Hepatol. Gastroenterol. 2019, 43, 575-584. [CrossRef]

61. Lao, Y.; Li, Y.; Zhang, P.; Shao, Q.; Lin, W.; Qiu, B.; Lv, Y.; Tang, L.; Su, S.; Zhang, H.; et al. Targeting Endothelial Erk1/2-Akt Axis as a Regeneration Strategy to Bypass Fibrosis during Chronic Liver Injury in Mice. Mol. Ther. 2018, 26, 2779-2797. [CrossRef] [PubMed]

62. Lv, J.; Bai, R.; Wang, L.; Gao, J.; Zhang, H. Artesunate may inhibit liver fibrosis via the FAK/Akt/beta-catenin pathway in LX-2 cells. BMC Pharmacol. Toxicol. 2018, 19, 64. [CrossRef] [PubMed]

(C) 2020 by the authors. Licensee MDPI, Basel, Switzerland. This article is an open access article distributed under the terms and conditions of the Creative Commons Attribution (CC BY) license (http://creativecommons.org/licenses/by/4.0/). 